\title{
Molecular identification of Prototheca zopfii genotype 2 mastitis isolates and their influence on the milk somatic cell count
}

\author{
Branko Suvajdžić ${ }^{*}$, Dragan Vasilev ${ }^{1}$, Neđeljko Karabasil ${ }^{1}$, \\ Ivan Vučurović́ ${ }^{2}$, Nikola Čobanović ${ }^{1}$, Milijana Babić1, and Vera Katić ${ }^{1}$ \\ ${ }^{1}$ Department of Hygiene and Food Technology, Faculty of Veterinary Medicine, University of Belgrade, \\ Belgrade, Serbia \\ ${ }^{2}$ Institute for Plant Protection and Environment, Belgrade, Serbia
}

\begin{abstract}
SUVAJDŽIĆ, B., D. VASILEV, N., KARABASIL, I. VUČUROVIĆ, N. ČOBANOVIĆ, M. BABIĆ, V. KATIĆ: Molecular identification of Prototheca zopfii genotype 2 mastitis isolates and their influence on the milk somatic cell count. Vet. arhiv 87, 249-258, 2017.
\end{abstract}

\section{ABSTRACT}

Algae from the genus Prototheca are the only plant-like microorganisms which can cause inflammation and alterations in the mammary gland. Prototheca mastitis is usually recognized as a chronic and symptomless disease with reduced milk production and a very high somatic cell count. Molecular identification of Prototheca spp. is helpful for the differentiation of pathogenic from non-pathogenic strains which are probably milk contaminants. Genotype-specific PCR assays, based on the $18 \mathrm{~S}$ rDNA gene sequences, have recently been developed to differentiate three genotypes of Prototheca zopfi, of which Prototheca zopfii genotype 3 was reclassified in a new species: Prototheca blaschkeae. P. zopfii genotype 2 is characterized as the main causative agent of Prototheca mastitis that leads to significant economic losses in primary milk production. The purpose of this study was to give a molecular characterization of Prototheca strains isolated in cases of subclinical and clinical mastitis, as well as to determine the influence of these pathogenic algae on the milk somatic cell count. After microbiological examination, algae from the genus Prototheca were isolated in pure cultures from 1.8\% of all tested milk samples, and all $13(100 \%)$ isolates were determined as Prototheca zopfii genotype 2 by a genotype-specific PCR. This study has provided the first molecular identification of Prototheca zopfii genotype 2 in the Republic of Serbia. In the case of subclinical Prototheca mastitis, the somatic cell count was 4,175,244 $\pm 1,233,685 / \mathrm{mL}$ of milk. A distinctly higher somatic cell count $(\mathrm{P}<0.05)$ was found in the quarters infected by Prototheca zopfii genotype 2 than in the quarters infected by Staphylococcus aureus, which is the most common mastitis causative agent worldwide. The results from this study support previous observations that $P$. zopfii genotype 2 is the main causative agent of Prototheca mastitis which leads to a significant increase in the somatic cell count in the milk.

Key words: Prototheca mastitis, Prototheca zopfii genotype 2, genotype-specific PCR, somatic cell count

\footnotetext{
*Corresponding author:

Branko Suvajdžić, DVM., Faculty of Veterinary Medicine, University of Belgrade, Bulevar Oslobođenja 18, Belgrade, Serbia, Phone: +381-64-2963648; Fax: +381-11-2685653; E-mail: brankosuvajdzic@yahoo.com
} 


\section{Introduction}

Udder health of cows in intensive cattle farming is significant for the hygiene and quality of produced milk, but also because of the profitability of production. Mastitis is an inflammation of the mammary gland occurring as a response to microorganism invasion and is characterized by physical, chemical and microbiological changes in the milk and pathological changes in the parenchyma of the mammary gland (SHARMA et al., 2011). Studies show that more than 137 different species of microorganisms are associated with the etiology of mastitis (BAČIĆ, 2009). Algae from the genus Prototheca are the only plant-like microorganisms which can cause inflammation and alterations in the mammary gland (JAGIELSKI et al., 2011). Prototheca mastitis is rapidly becoming a problem worldwide (BUZZINI et al., 2004; SCACCABAROZZI et al., 2008; RICCHI et al., 2010 ) and in the Republic of Serbia it was diagnosed and described first by MILANOV et al. (2006).

Members of the genus Prototheca are unicellular, colorless algae that reproduce asexually by endosporulation. Considering the fact that during the phylogeny lost chlorophyll these algae do not have photosynthetic ability, while species such as Prototheca zopfii (P. zopfii), Prototheca wickerhamii (P. wickerhamii) and Prototheca blaschkeae (P. blaschkeae) have become pathogenic for humans and animals (MARQUES, 2010). Infections in animals are usually caused by $P$. zopfii while human infections are mostly associated with $P$. wickerhamii (ROESLER and HENSEL, 2003). Previously, $P$. zopfii differentiated biochemically and serologically into three different biotypes, but at the last classification based on molecular characteristics, $P$. zopfii biotype 1 and biotype 2 were reclassified as $P$. zopfii genotype 1 and genotype 2, while $P$. zopfii biotype 3 was reclassified in a new species (P. blaschkeae) (ROESLER et al., 2006).

P. zopfii genotype 2 was characterized as the main causative agent of Prototheca mastitis in Germany, Italy, Japan, Portugal and Poland, after molecular characterization of mastitis isolates (ROESLER et al., 2006; MÖLLER et al., 2007; MARQUES et al., 2008; OSUMI et al., 2008; RICCHI et al., 2010; JAGIELSKI et al., 2011). Sporadic cases of mastitis caused by P. blaschkeae have also been confirmed, but less frequently (MARQUES et al., 2008; RICCHI et al., 2010; JAGIELSKI et al., 2011). The presence of these pathogenic algae on a farm poses the risk of mastitis, while bad hygiene conditions and poor milking hygiene only contribute to the spread of infection in the herd (ROESLER and HENSEL, 2003). Dairy cows are susceptible to infections in all stages of lactation, including the dry period (RICCHI et al., 2010). Despite low virulence, pathogenic algae can cause an expressed mammary gland immune response, which results in very high somatic cell content elevation (SCC) (over $10^{6} / \mathrm{mL}$ ) as well as irreversible changes in the mammary gland tissue (JANOSI et al., 2001). Prototheca mastitis is usually recognized as a chronic and symptom-less disease, with reduced milk production and very high SCC. However, 
Prototheca mastitis can appear in a clinically visible form characterized by a thin watery secretion containing white flakes and lumps (MARQUES, 2010). Successful therapy and spontaneous recovery of infected animals have not been reported (WAWRON et al., 2013). Therefore, it is necessary to exclude infected cows from production in order to reduce the risk of spread of the infection to other animals and contamination of the environment (LOPES et al., 2008).

Timely detection of mastitis caused by algae from the genus Prototheca and their identification is extremely important from the aspect of epidemiology and farm management. The aim of this study was to provide molecular characterization of Prototheca strains isolated in cases of subclinical and clinical mastitis, as well as to determine the influence of these pathogenic algae on the SCC in milk.

\section{Materials and methods}

Milk sampling. Quarter milk samples were collected aseptically from cows in which the California mastitis test indicated increased SCC, or from cows with clinical mastitis. A total of 726 milk samples were collected from 193 caws.

Microbiological examination. For isolation of Prototheca spp. strains, $0.1 \mathrm{~mL}$ milk of each sample was streaked onto Columbia agar plates, supplemented with 5\% sheep blood and Sabouraud agar with chloramphenicol $(0.05 \mathrm{~g} / \mathrm{L})$, following incubation for $72 \mathrm{~h}$ at 37 ${ }^{\circ} \mathrm{C}$ under aerobic conditions, and microbial growth was monitored daily. After incubation, the morphology of the isolated colonies was evaluated. Typical colonies were chosen for making Gram-stained microscopic preparations. The preparations were examined using light microscopy with immersion $(\times 100)$. Identification of other mastitis causative agents isolated on blood agar was performed according to the standard procedures (KATIĆ, 2007a). The API Staph-Ident system (BioMérieux, France) was used for identification of Staphylococcus aureus (S. aureus) isolates. In order to obtain single colonies needed for DNA extraction, isolates of Prototheca spp. were subcultured on Trypticase soy agar at $37^{\circ} \mathrm{C}$ for $48 \mathrm{~h}$.

DNA extraction. Extraction of genomic DNA was carried out with a DNeasy Plant Mini kit (Qiagen ${ }^{\circledR}$, Germany) following the manufacturer's instructions. The extracted DNA was used as a template for PCR amplification

PCR assay. After DNA extraction, 13 Prototheca spp. strains were analyzed by a modified genotype-specific PCR procedure (ROESLER et al., 2006). The genotype-specific primers used in this study are listed in Table 1, and were synthesized by Invitrogen (United States). All PCR reactions were performed in $50 \mu \mathrm{L}$ reaction volumes containing $25 \mu \mathrm{L}$ Dream Taq Master Mix (2X) containing 2× Dream Taq buffer, $4 \mathrm{mM} \mathrm{MgCl} 2$ and $0.4 \mathrm{mM}$ of each of the $4 \mathrm{dNTPs}$ (Thermo Scientific, Lithuania), $0.8 \mu \mathrm{M}$ of each primer, $5 \mu \mathrm{L}$ DNA, and nuclease free water to $50 \mu \mathrm{L}$. DNA amplification was performed in a 
FlexCycler (AnalyticJena, Germany). The PCR program specific for P. zopfii genotype 1 and 2 was: (1) initial denaturing step at $94{ }^{\circ} \mathrm{C}$ for $4.5 \mathrm{~min}$; (2) 30 cycles of $30 \mathrm{~s}$ at 94 ${ }^{\circ} \mathrm{C}, 30 \mathrm{~s}$ at $58{ }^{\circ} \mathrm{C}$, and $40 \mathrm{~s}$ at $72{ }^{\circ} \mathrm{C}$; and (3) a final extension step at $72{ }^{\circ} \mathrm{C}$ for $5 \mathrm{~min}$. The PCR program specific for P. blaschkeae was: (1) initial denaturing step at $94{ }^{\circ} \mathrm{C}$ for $4.5 \mathrm{~min}$; (2) 35 cycles of $30 \mathrm{~s}$ at $94{ }^{\circ} \mathrm{C}, 30 \mathrm{~s}$ at $63{ }^{\circ} \mathrm{C}$, and $40 \mathrm{~s}$ at $72{ }^{\circ} \mathrm{C}$; and (3) a final extension step at $72{ }^{\circ} \mathrm{C}$ for $5 \mathrm{~min}$. A negative control was included in all PCR reactions. Amplification products were analyzed by electrophoresis on $1.6 \%(\mathrm{wt} / \mathrm{vol})$ agarose gel (TopVision agarose Thermo Scientific, Lithuania), after staining with ethidium bromide. A molecular size marker (Gene Ruler 100 bp DNA ladder, ThermoScientific, Lithuania) was used as the molecular weight marker.

Table 1. Primers used in genotype-specific PCR analysis for Prototheca spp. mastitis isolates

\begin{tabular}{|l|l|l|}
\hline \multirow{2}{*}{ Genotype } & Primer & Sequence $\left(5^{\prime}-3^{\prime}\right)$ \\
\hline \multirow{2}{*}{ Genotype 1 } & Proto 18-4f & GACATGGCGAGGATTGACAGA \\
\cline { 2 - 3 } & PZGT 1/r1 & GCCAAGGCCCCCGAAG \\
\hline \multirow{2}{*}{ Genotype 2 } & Proto 18-4f & GACATGGCGAGGATTGACAGA \\
\cline { 2 - 3 } & PZGT 2/r1 & GTCGGCGGGGCAAAAGC \\
\hline \multirow{2}{*}{ Genotype 3 } & PZGT 3-IK/f & CAGGGTTCGATTCCGGAGAG \\
\cline { 2 - 3 } & PZGT 3/r1 & GTTGGCCCGGCATCGCT \\
\hline
\end{tabular}

Somatic cells counting. SCC in milk samples was determined using the microscopic method according to the standard SRPS EN ISO 13366-1:2010 - part 1.

Statistical analysis. Statistical analysis of the results was conducted using the software GraphPad Prism version 5.00 for Windows (GraphPad Software, San Diego Ca, USA, www.graphpad.com). Results of SCC were described by descriptive statistics (mean, maximum, minimum and standard deviation). The Student t-test was used for testing the differences between SCC in milk samples from cows with Prototheca mastitis and mastitis caused by $S$. aureus. Values of $\mathrm{P}<0.05$ were considered significant.

\section{Results}

The present research was conducted to determine the cause of the increased SCC in the bulk milk. During sampling, it was found that $46(5.96 \%)$ dried udder quarters had resulted from unsuccessful antibiotics treatment of chronic mastitis. Bad hygiene conditions, primarily unclean and humid accommodation for the cows, were also observed during the sampling. These findings indicated a problem with subclinical mastitis in the herd. The causes of mastitis were isolated from 86 milk samples $(11.85 \%$ of all tested milk samples). Coagulase negative staphylococci were proven in 32 samples (4.41\%), Corynebacterium bovis in 27 samples $(3.72 \%)$, S. aureus in 9 samples $(1.24 \%)$, 
Strteptococcus uberis and Escherichia coli in 2 samples $(0.28 \%)$ while yeast was isolated from only 1 sample $(0.14 \%)$. Algae from the genus Prototheca were observed on the blood agar as small round grey colonies, with a characteristic yeast-like appearance, while on the Sabouraud agar with $0.05 \mathrm{~g} / \mathrm{L}$ chloramphenicol this microorganism formed white colonies 1-3 mm in diameter, with a granular surface. Gram-stained microscopic preparations demonstrated blue, sometimes red, oval-shaped sporangia containing endospores. As such, algae from the genus Prototheca were isolated in pure cultures from 13 milk samples ( $1.8 \%$ of all tested milk samples).

In order to identify isolates of Prototheca spp. which were isolated in cases of bovine mastitis, three variable regions of the 18S rDNA genes were amplified by PCR. All 13 isolates were identified as $P$. zopfii genotype 2, since the amplicon (165 bp) specific for P. zopfi genotype 2 (Fig. 1) was observed. The PCR specific for $P$. zopfii genotype 1 was always negative, as was the PCR specific for P. blaschkeae.

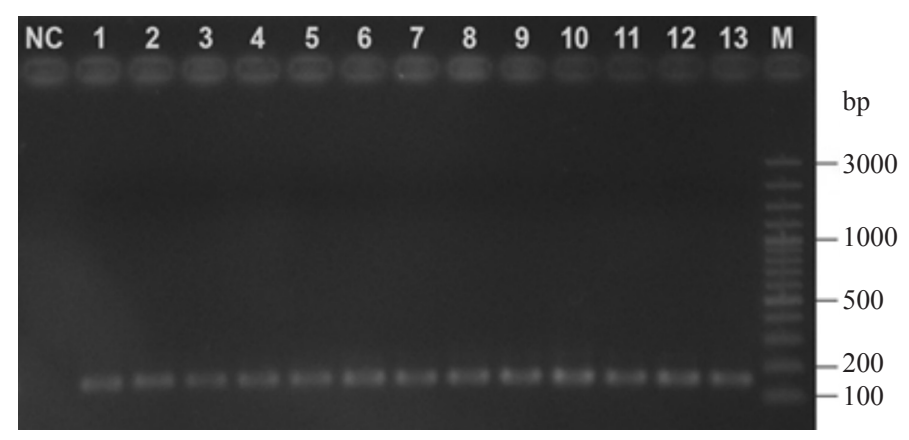

Fig. 1. Results of genotype-specific PCR analysis for Prototheca spp. mastitis isolates.

NC: negative control; Lines 1-13: P. zopfii genotype 2 mastitis isolates; M: molecular weight marker.

Molecular identification of $P$. zopfii genotype 2 and the results of SCC in milk from infected quarters were sufficient for diagnosis of Prototheca mastitis. This pathogenic alga caused expressed immune response in the mammary gland in all infected cows which may be seen from the results of SCC in the milk. In the case of subclinical Prototheca mastitis, the SCC ranged from 2,150,842 to $5,308,737 / \mathrm{mL}$ of milk, while in milk from quarters subclinically affected by $S$. aureus it ranged between 477,895 and 2,204,210/ $\mathrm{mL}$. A statistically significant difference $(\mathrm{P}<0.05)$ was established between $\mathrm{SCC}$ in milk samples from cows with Prototheca mastitis and mastitis caused by S. aureus (Fig. 2). 
B. Suvajdžić et al.: Molecular identification of Prototheca zopfii genotype 2 mastitis isolates

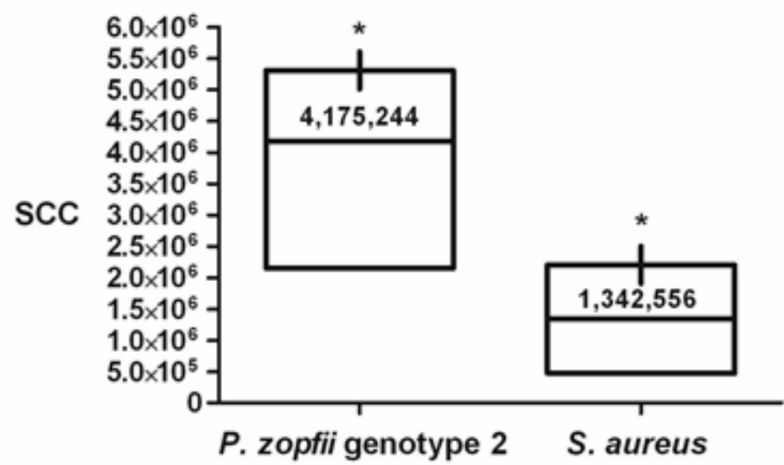

Fig. 2. Somatic cell count in case of subclinical mastitis caused by $P$. zopfii genotype 2 and subclinical mastitis caused by $S$. aureus. $* \mathrm{P}<0.05$

\section{Discussion}

Prototheca mastitis is rapidly becoming a problem worldwide (BUZZINI et al., 2004; SCACCABAROZZI et al., 2008; RICCHI et al., 2010) and in the Republic of Serbia it was first diagnosed and described by MILANOV et al. (2006) but without molecular characterization of Prototheca strains. Genotype-specific PCR assays, based on the 18S rDNA gene sequences, have recently been developed to differentiate three genotypes of Prototheca zopfii, of which Prototheca zopfii genotype 3 was reclassified in a new species Prototheca blaschkeae (ROESLER et al., 2006). This study represents the first molecular determination of algae from the genus Prototheca isolated from bovine mastitis in the Republic of Serbia.

After microbiological examination, algae from the genus Prototheca were isolated in pure cultures from $1.8 \%$ of all tested milk samples, and all $13(100 \%)$ isolates were determined as $P$. zopfii genotype 2 by genotype-specific PCR. The results of this study are in agreement with the findings of MÖLLER et al. (2007) from Germany and OSUMI et al. (2008) from Japan, which also identified only P. zopfii genotype 2 from bovine mastitis. In contrast to the results obtained in our study, the findings of MARQUES et al. (2008) from Portugal, RICCHI et al. (2010) from Italy and JAGIELSKI et al. (2011) from Poland indicate P. blaschkeae as the causative agent of mastitis instead of P. zopfii genotype 2. RICCHI et al. (2010) pointed out that the mastitis caused by P. blaschkeae occurs less frequently, while $P$. zopfii genotype 2 is major Prototheca mastitis causative agent. The same authors confirmed the status of $P$. zopfii genotype 1 as an environmental organism, with no involvement in pathology of mammary glands. Therefore, molecular identification of Prototheca spp. is helpful for differentiation of pathogenic from non-pathogenic strains which are probably milk contaminants (MÖLLER et al., 2007). 
Although P. zopfii genotype 2 was isolated only from 1.8\% milk samples (in $4.66 \%$ of all examined cows), this finding is not negligible, considering that infected cows are a source of infection for other animals in the herd (MILANOV et al., 2006). P. zopfii genotype 2 can survive for a long time in the udder, even during the dry period, because the udder's antimicrobial defense mechanism cannot overcome and eliminate this pathogen (RICCHI et al., 2010). Despite low virulence, $P$. zopfii genotype 2 may cause serious problems in the herd of dairy cows and induces endemic infections. Consequently, individual cases of Prototheca mastitis in a herd also require alertness (WAWRON et al., 2013).

According to previous studies, Prototheca mastitis is usually subclinical or clinical, with mild symptoms (JANOSI et al., 2001; MARQUES, 2010; WAWRON et al., 2013). These data are supported by the findings of this study where only two cows had expressed clinical mastitis without visible changes to the udder, but with milk alterations (watery appearance and the presence of white flakes), while other cows had a subclinical form of Prototheca mastitis characterized by decreased milk production and SCC elevation.

In the milk of healthy cows the SCC is lower than $1 \times 10^{5}$ cells $/ \mathrm{mL}$ (BYTYQI et al., 2010), while an increase in the SCC above $2 \times 10^{5} / \mathrm{mL}$ of milk is usually the result of intramammary infection. The strength of the mammary gland immune response depends on the type of pathogen or its virulence (SHARMA et al., 2011). Despite low virulence, P. zopfii can cause expressed mammary gland immune response, which results in SCC elevation from $1 \times 10^{6}$ to $1 \times 10^{7} \mathrm{cells} / \mathrm{mL}$ of milk (JAGIELSKI et al., 2011). This is in accordance with the data obtained in the present study, where SCC was 4,175,244 \pm $1,233,685 / \mathrm{mL}$ of milk. MALINOWSKI et al. (2002) found that SCC in cases of subclinical Prototheca mastitis ranges from 591,000 to $3,072,000 / \mathrm{mL}$ of milk, which are slightly lower values than our findings. Distinctly higher SCC $(\mathrm{P}<0.05)$ was found in quarters infected by $P$. zopfii genotype 2 than in the quarters infected by $S$. aureus, which is the most common mastitis causative agent worldwide (BAČIĆ, 2009). SCC is a useful indicator of intramammary infection and a very important milk component in assessment of milk quality and hygiene (SHARMA et al., 2011). The increased incidence of subclinical mastitis in a herd leads to SCC elevation in bulk milk. Therefore, any increase in SCC in bulk milk indicates the need to test milk from individual udder quarters in order to identify cows with subclinical mastitis, and it also requires determination of the causative agent of mastitis (KATIĆ, 2007b).

In conclusion, the results from this study support previous observations that $P$. zopfii genotype 2 is the main causative agent of Prototheca mastitis which leads to a significant increase in SCC in the milk. In order to determine the prevalence of $P$. zopfii genotype 2 in the Republic of Serbia, as well as to clarify the epidemiology of this pathogenic algae, it is necessary to include a greater number of milk samples from different geographic localities. 
B. Suvajdžić et al.: Molecular identification of Prototheca zopfii genotype 2 mastitis isolates

\section{Acknowledgements}

The research was supported by the Ministry of Education, Science and Technology Development of the Republic of Serbia, Grant number: 31086 .

\section{References}

BAČIĆ, G. (2009): Diagnostic and mastitis treatment in dairy cows. Faculty of Veterinary Medicine, University of Zagreb, Zagreb, pp. 29-45. (in Croatian)

BUZZINI, P., B. TURCHETTI, R. FACELLI, R. BAUDINO, F. CAVARERO, L. MATTALIA, P. MOSSO, A. MARTINI (2004): First large-scale isolation of Prototheca zopfii from milk produced by dairy herds in Italy. Mycopathologia 158, 427-430.

BYTYQI, H., U. ZAUGG, K. SHERIFI, A. HAMIDI, M. GJONBALAJ, S. MUJI, H. MEHMETI (2010): Influence of management and physiological factors on somatic cell count in raw milk in Kosova. Vet. arhiv 80, 173-183.

JAGIELSKI, T., H. LASSA, J. AHRHOLDT, E. MALINOWSKI, U. ROESLER (2011): Genotyping of bovine Prototheca mastitis isolates from Poland. Vet. Microbiol. 149, 283-287.

JANOSI, S., F. RATZ, G. SZIGETI, M. KULCSAR, J. KERENYI, T. LAUKO, F. KATONA, G. HUSZENICZA (2001): Review of the microbiological, pathological, and clinical aspects of bovine mastitis caused by algae Prototheca zopfii. Vet. Quart. 23, 58-61.

KATIĆ, V. (2007a): Diagnostic of mastitis. In: Guide for Milk Hygiene (Belgrade: Zuhra). Veterinarska komora Srbije, pp. 54-68. (in Serbian)

KATIĆ, V. (2007b): The somatic cell counts in milk quality assessment (in Serbian). Savremena poljoprivreda $56,5,33-41$.

LOPES, M. M., R. RIBEIRO, D. CARVALHO, G. FREITAS (2008): In vitro antimicrobial susceptibility of Prototheca spp. isolated from bovine mastitis in a Portugal dairy herd. J. Myc. Med. 18, 205-209.

MALINOWSKI, E., H. LASSA, A. KŁOSSOWSKA (2002): Isolation of Prototheca zopfii from inflamed secretion of udders. Bull. Vet. Inst. Pulawy 46, 295-299.

MARQUES, S., E. SILVA, C. KRAFT, J. CARVALHEIRA, A. VIDEIRA, A. R OLKER, G HOMPSON (2008): Bovine mastitis associated with Prototheca blaschkeae. J. Clin. Microbiol. 46, 1941-1945.

MARQUES, S. (2010): Protothecosa: Agent Characterization and Pathogenesis. PhD Thesis, Porto University, Porto, Portugal.

MILANOV, D., L. SUVAJDŽIĆ, I. PUŠIĆ, B. VIDIĆ, V. DORDEVIĆ-MILIĆ (2006): Outbreak of endemic form of protothecal mastitis on a dairy farm. Acta Vet. (Beograd) 56, 259-265.

MÖLLER, A., U. TRUYEN, U. ROESLER (2007): Prototheca zopfii genotype 2. The causative agent of protothecal mastitis? Vet. Microbiol. 120, 370-374. 
B. Suvajdžić et al.: Molecular identification of Prototheca zopfii genotype 2 mastitis isolates

OSUMI, T., Y. KISHIMOTO, R. KANO, H. MARUYAMA, M. ONOZAKI, K. MAKIMURA, T. ITO, K. MATSUBARA, A. HASEGAWA (2008): Prototheca zopfii genotypes isolated from cow barns and bovine mastitis in Japan. Vet. Microbiol. 131, 419-423.

RICCHI, M., M. GORETTI, E. BRANDA, G. CAMMI, C. A. GARBARINO, B. TURCHETTI, P. MORONI, N. ARRIGONI, P. BUZZINI (2010): Molecular characterization of Prototheca strains isolated from Italian dairy herds. J. Dairy Sci. 93, 4625-4631.

ROESLER, U., A. HENSEL (2003): Longitudinal analysis of Prototheca zopfi-specific immune responses: correlation with disease progression and carriage in dairy cows. J. Clin. Microbiol. 41, 1181-1186.

ROESLER, U., A. MÖLLER, A. HENSEL, D. BAUMANN, U. TRUYEN (2006): Diversity within the current algal species Prototheca zopfii: a proposal for two Prototheca zopfii genotypes and description of a novel species, Prototheca blaschkeae sp. nov. Int. J. Syst. Evol. Microbiol. 56, 1419-1425.

SCACCABAROZZI, L., B. TURCHETTI, P. BUZZINI, G. PISONI, L. BERTOCCHI, N. ARRIGONI, P. BOETTCHER, V. BRONZO, P. MORONI (2008): Isolation of Prototheca spp. strains from environmental sources of dairy herds. J. Dairy Sci. 91, 3474-3477.

SHARMA, N., N. K. SINGH, M. S. BHADWAL (2011): Relationship of somatic cell count and mastitis: an overview. Asian-Aust. J. Anim. Sci. 24, 429-438.

SRPS EN ISO 13366-1:2010 - part 1. Milk - Enumeration of somatic cells - Part 1: Microscopic method (Reference method).

WAWRON, W., M. BOCHNIARZ, T. PIECH, W. LOPUSZYNSKI, J. WYSOCKI (2013): Outbreak of protothecal mastitis in a herd of dairy cows in Poland. Bull. Vet. Inst. Pulawy 57, 335-339.

Received: 19 December 2015

Accepted: 29 August 2016

\section{SUVAJDŽIĆ, B., D. VASILEV， N. KARABASIL，I. VUČUROVIĆ，N. ČOBANOVIĆ, M. BABIĆ, V. KATIĆ: Molekularna identifikacija izolata Prototheca zopfii genotip 2 izdvojenih kod mastitisa krava i njihov utjecaj na broj somatskih stanica u mlijeku. Vet. arhiv 87, 249-258, 2017.} SAŽETAK

Alge roda Prototheca mikroorganizmi su nalik na biljke koji mogu uzrokovati upalu i promjene u mliječnoj žlijezdi. Njima uzrokovan mastitis obično je kroničnog tijeka, bez izraženih znakova bolesti, ali dovodi do smanjene proizvodnje mlijeka i do vrlo visokog broja somatskih stanica. Molekularna identifikacija Prototheca spp. korisna je za razlikovanje patogenih od nepatogenih sojeva koji su vjerojatno kontaminanti mlijeka. Nedavno su razvijeni genotip-specifični PCR postupci zasnovani na sekvenciji gena $18 \mathrm{~S}$ rDNK s ciljem da se razlikuju tri genotipa vrste Prototheca zopfii, od kojih je Prototheca zopfii genotip 3 preimenovan u novu vrstu, Prototheca blaschkeae. Prototheca zopfii genotip 2 okarakteriziran je kao glavni uzročnik mastitisa uzrokovanog prototekama koji dovodi do značajnih gospodarskih gubitaka u primarnoj proizvodnji mlijeka. Cilj je ovog istraživanja bio da se izvrši molekularna identifikacija Prototheca sojeva izdvojenih u slučaju supkliničkih i kliničkih mastitisa, kao i da se utvrdi utjecaj tih patogenih algi na broj somatskih stanica u 
B. Suvajdžić et al.: Molecular identification of Prototheca zopfii genotype 2 mastitis isolates

mlijeku. Nakon mikrobiološke pretrage, alge iz roda Prototheca bile su izdvojene u čistoj kulturi iz 1,8 \% pretraženih uzoraka mlijeka i svih 13 (100\%) izolata su pomoću PCR identificirani kao Prototheca zopfii genotip 2. Ova studija predstavlja prvu molekularnu identifikaciju Prototheca zopfii genotip 2 u Republici Srbiji. U slučaju supkliničkih Prototheca mastitisa broj somatskih stanica bio je $4175244 \pm 1233685$ / mL mlijeka. Izrazito veći broj somatskih stanica $(\mathrm{P}<0,05)$ utvrđen je u četvrtima inficiranim genotipom 2 Prototheca zopfii nego u četvrtima inficiranima vrstom Staphylococcus aureus, koji je najčešći uzročnik mastitisa u krava diljem svijeta. Rezultati ove studije potvrđuju prethodna promatranja da je Prototheca zopfii genotip 2 glavni uzročnik Prototheca mastitisa koji dovodi do značajnog porasta broja somatskih stanica u mlijeku.

Ključne riječi: mastitis, Prototheca zopfii genotip 2, genotip-specifičan PCR, broj somatskih stanica 